\title{
PRINSIP - PRINSIP PENGELOLAAN PEMANFAATAN TANAH WAKAF GUNA PENINGKATKAN KESEJAHTERAAN MASYARAKAT
}

\author{
Oleh: \\ Suhirman ${ }^{1}$ \\ ABSTRACT
}

Donated land based on wakaf in Indonesia has agreat potential to help fulfill the needs in the field of religion and socio economy of the society, the donation of lands in general must be managed effectively and efficiently based on the purposes and functions under Islamic Law.

Donations of land in Indonesia have been known and implemented by Muslims since Islam came to Indonesia. The wakaf donation as one of the Islamic institutions in Indonesia has supported the religious life of Islam in particular and the social life of Indonesian in general. Almost all buildings functioned for the social and religious interests such as worshipping places, educational complex, hospital, bording houses, or public facilities stand on land donated by wakaf. However, it is also realized that there arestill donated lands that have not been optimally managed.

Donated in general and donated land based on wakaf in particular if managed professionally can give contributions to the community's economy in order to develop public welfare. Wakaf donations actually have agreat potential to be managed and empowered and turned into business purposes in accordance with the economic productivity, not only functioned as a means for worshipping places.

\section{Keywords : wakaf as one of the Islamic institutions.}

\section{PENDAHULUAN \\ 1. Latar Belakang Masalah}

Perkembangan Islam di Indonesia secara historis tidak dapat terpisahkan dengan perwakafan, yang mana potensi wakaf dapat dipakai sebagai penunjang pada dakwah Islamiah. ${ }^{2}$

Setiap bangunan yang difungsikan untuk kepentingan keagamaan dan sosial, baik yang berupa tempat ibadah, komplek

Mahasiswa Magister Ilmu Hukum Universitas Udayana, Denpasar, Bali,Alamat Jl. Melati No. 21 Monang Maning Denpasar.

2 Abdul Ghafur Anshori, 2005, Hukum Dan Praktek Perwkafan Di Indonesia, Pilar Media, Jogyakarta, hlm.2. pendidikan, pusat penyiaran Islam, asrama ataupun tempat amal kebajikan yang lainnya itu, selama ini memang pada umumnya berdiri diatas tanah wakaf.

Wakaf sebagai suatu lembaga Islam menjadi salah satu penunjang bagi perkembangan kehidupan agama dan sosial ekonomi masyarakat Islam di Indonesia.

Harta benda tanah wakaf di Indonesia mempunyai potensi yang amat besar guna membantu terhadap pemenuhan berbagai kebutuhan kepentingan masyarakat, seperti untuk kepentingan keagamaan, kepentingan sosial dan ekonomi. Oleh karenanya masalah perwakafan tanah milik perlu diatur dan dikelola dengan secermat mungkin. 
Sebagai salah satu wujud nyata upaya pengaturan pengelolaan tanah wakaf itu adalah dengan telah disusun dan disahkannya Undang-Undang No. 41 Tahun 2004 tentang Wakaf. Dalam pertimbangannya huruf (a) disebutkan bahwa lembaga wakaf sebagai pranata keagamaan yang memiliki potensi dan manfaat ekonomi perlu dikelola secara efektif dan efisien untuk kepentingan ibadah dan untuk memajukan kesejahteraan umum.

Tujuan dan fungsi wakaf adalah untuk mewujudkan potensi dan manfaat ekonomis harta benda wakaf guna kepentingan ibadah dan untuk memajukan kesejahteraan umum, maka harta benda wakaf khususnya yang berupa tanah milik harus dikelola secara efektif dan efisien. Namun dalam realitanya harapan untuk mewujudkan suatu tujuan dan fungsi wakaf itu belum dapat terrealisir sepenuhnya.

Banyak harta benda tanah tanah wakaf di dalam masyarakat kita yang mempunyai potensi dan manfaat ekonomi sangat besar guna peningkatan kesejahteraan kehidupan masyarakat itu belum dilakukan pengelolaannya secara produktifitas ekonomi dengan suatu usaha yang optimal.

Sangat disayangkan bahwa dalam usaha-usaha pengelolaan harta tanah wakaf yang kearah peningkatan kesejahteraan umum itu belum sepenuhnya dapat terwujud seperti yang diharapakan, pada hal potensi dan manfaat ekonomi dalam harta benda tanah wakaf itu sangat besar. Hal ini merupakan suatu tantangan dalam lembaga wakaf khususnya bagi pengelola harta benda tanah wakaf agar segera dapat mengelolanya secara produktifitas ekonomi.
Pengelolaan pemanfaatan harta tanah wakaf diperlukan adanya prinsip dasar yang jelas. Jangan sampai potensi dan manfaat ekonomi yang begitu besar yang dapat dipakai sebagai modal untuk meningkatkan kesejahteraan kehidupan masyarakat itu disia-siakan begitu saja.

Potensi dan manfaat ekonomis harta benda wakaf itu apabila dikelola secara profesional dapat memberikan kontribusi terhadap pemenuhan kebutuhan ekonomi masyarakat sehingga dapat membantu untuk meningkatkan kesejahteraan masyarakat.

\section{Rumusan masalah}

Berdasarkan penjelasan latar belakang tersebut maka dapat dirumuskan masalah sebagai berikut:

Bagaimanakah prinsip dasar dalam pemanfaatan pengelolaan harta tanah wakaf guna membantu meningkatkan kesejahteraan kehidupan ekonomi masyarakat?

\section{Metode pendekatan}

Dalam pengkajian terhadap permasalahan tersebut diatas dipergunakan pendekatan secara normatif.

\section{PEMBAHASAN}

Pengertian wakaf sebagaimana yang tersurat didalam pasal 1 ayat(1) UndangUndang Nomor 41 Tahun 2004 tentang Wakaf, ditentukan wakaf adalah perbuatan hukum wakif untuk memisahkan dan/atau menyerahkan sebagian harta benda miliknya untuk dimanfaatkan selamanya atau untuk jangka waktu tertentu sesuai dengan kepentingannya guna keperluan ibadah dan/ atau kesejahteraan umum menurut syariah. 
Wakaf di Indonesia telah diatur dalam Undang-Undang Nomor 41 Tahun 2004 tentang Wakaf, yang secara substansial telah memadai. Pelaksanaan perwakafan di Indonesia telah ditentukan bahwa untuk sahnya suatu wakaf secara formal harus ada Akta Ikrar Wakaf (AIW) yang dibuat oleh Pejabat Pembuat Akta Ikrar Wakaf sebagai lembaga yang berwenang menurut undangundang yang berlaku, dengan demikian ada bukti formal yang kuat. Wakaf dikalangan masyarakat Islam di Indonesia sudah terbiasa bahkan sudah membudaya sehingga tidak ada keraguan untuk melaksanakannya.

Menurut teori sistem hukum dari Lawrence M Friedman dalam bukunya yang berjudul The Legal System, A Social Science Perspective, 1975 dinyatakan bahwa a legal system in actual operation is a complex organism inwich structure, substance and culture interact. ${ }^{3}$ Dinyatakan bahwa sebagai sistem hukum di dalamnya tercakup substansi, struktur dan budaya hukum sebagai satu kesatuan. Sehingga jika ditinjau dari segi sistem hukum eksistensi perwakafan di Indonesia sudah tepat.

Wakaf itu merupakan bagian dari ibadah, ${ }^{4}$ baik menyangkut keagamaan maupun sosial. Dilihat dari segi religius substansi dalam praktek pelaksanaan perwakafan mempunyai fungsi sebagai ritual dalam arti sebagai suatu bentuk implemantasi dari keimanan seseorang yaitu sebagai amal shaleh yang dipercaya pahalanya akan

Lawrence M Friedman, 1975, The Legal System, A Social Science Perspective, Rusell Sage Foundation, New York hlm.16

4 Sholeh Soan, 2004, Moral Penegak Hukum di Indonesia Dalam Pandangan Islam, Agung Ilmu,Bandung, hlm.7 mengalir secara terus menerus dapat dipakai sebagai bekal kehidupan kelak diakhirat nanti. Pada sisi yang lain pelaksanaan perwakafan juga mempunyai fungsi sosial yaitu bahwa harta tanah wakaf itu dalam pengelolaan pemanfaatannya sebagai bentuk solidaritas sosial yang dijadikan sebagai instrument pendukung terhadap peningkatan kesejahteraan masyarakat yang bersifat abadi. Maka wakaf sifatnya sebagai amal jariah, selama benda yang diwakafkan itu dapat dimanfaatkan oleh orang banyak maka selama itu pula pahalanya akan mengalir terus kepadanya. ${ }^{5}$

Peran wakaf merupakan salah satu langkah setrategis guna meningkatkan kesejahtraan masyarakat. Peningkatan peran wakaf sebagai pranata keagamaan tidak hanya bertujuan untuk menyediakan berbagai sarana tempat ibadah dan sosial, tetapi wakaf juga memilik potensi kekuatan ekonomi untuk memajukan kesejahteraan masyarakat, maka pengelolaan harta tanah wakaf perlu dikembangkan kearah pemanfaatan produktifitas ekonomi.

Keberadaan harta tanah wakaf yang begitu banyak sejalan dengan kehidupan masyarakat Indonesia yang mayoritas beragama Islam, yaitu sekitar 89 persen penduduk Indonesia mengaku beragama Islam, ${ }^{6}$ harta tanah wakaf ini merupakan suatu potensi yang amat besar untuk dapat dikelola secara produktifitas ekonomi, guna meningkatkan kesejhteraan masyarakat.

Tahir Azhari,1992, Wakaf dan Sumber Daya Ekonomi, Al Hikmah, Jakarta, hlm.11

Muhammad Daud Ali, 1990, Asas-Asas Hukum Islam, CV Rajawali, Jakarta hlm.5 
Lembaga wakaf merupakan suatu lembaga yang memiliki peranan sangat penting dalam perkembangan masyarakat Islam baik dalam bidang keagamaan, bidang pendidikan, ekonomi dan sosial. ${ }^{7}$ Salah satu peran dari lembaga wakaf adalah untuk meningkatkan kesejahteraan ekonomi massyarakat. Sebagaimana disebutkan dalam jiwa semangat pembentukan UndangUndang Nomor 41 tahun 2004 tentang Wakaf, bahwa lembaga wakaf sebagai pranata keagamaan yang memiliki potensi dan manfaat ekonomi perlu dikelola secara efektif dan efisien untuk kepentingan ibadah dan untuk memajukan kesejahteraan umum.

Secara normatif pengelolaan harta tanah wakaftersebut merupakan kewenangan dari Nazhir. Berhasil atau tidaknya dalam pengelolaan harta tanah wakaf itu sangat bergantung kepada Nazhir, oleh karenanya agar pengelolaan harta tanah wakaf itu dapat berjalan secara efektif dan efisien guna memajukan kesejahteraan masyarakat maka perlu dilandasi adanya prinsip-prinsip dasar sebagai berikut.

1. Pengelolaan harta tanah wakaf harus berdasarkan pada asas-asas yang jelas

Pengelolaan harta benda wakaf yang berorientasi kepada peningkatan kesejahteraan umum, maka secara tehnis pengelolaan wakaf ini perlu diterapkan asas manfaat, asas tanggungjawab, asas profesionalitas, asas keadilan sosial sebagai landasan. ${ }^{8}$

Juhaya S Praja \& Mukhlisin Muzairie, 2009, Pranata Ekonomi Islam Wakaf, Pustaka Dinamika, Jogyakarta, hlm.11.

8 Abdul Manan, 2007, Hukum Wakaf Dalam Paradigma Baru di Indonesia, Varia Peradilan No. 255, Februari 2007, hlm.50.

\section{a. Asas manfaat.}

Berdasarkan keyakinan bahwa berwakaf memiliki suatu nilai manfaat yang bersifat abadi yang pahalanya mengalir terus menerus selama benda wakaf tersebut ;

1. Dapat dimanfaatkan oleh orang banyak. Contoh mewakafkan tanah untuk dibangun sekolah dimana sekolah tersebut dapat dimanfaatkan oleh masyarakat sebagai sarana penyelenggaraan pendidikan.

2. Dapat memberikan nilai manfaat yang lebih nyata sesuai dengan tujuan dan fungsi wakaf yang telah ditentukan oleh wakif, bahwa harta yang telah diwakafkan tersebut sungguh-sungguh memberikan manfaat kepada orang lain, sehingga wakif merasa ada kepuasan secara batiniah.

3. Dapat memberikan nilai manfaat secara immaterial yang lebih besar dari pada nilai materiilnya yaitu berupa pahala yang tak terbatas besarnya yang akan diperoleh oleh Wakif.

4. Tidak menimbulkan keburukan (mudharat) baik bagi masyarakat banyak maupun bagi wakif sendiri.

\section{b. Asas tanggungjawab.}

Pelaksanaan pengelolaan harta benda wakaf mutlak diperlukan adanya pertanggungjawaban. Perwakafan didalamnya mengandung aspek ibadah murni Ilahiyah dan aspek ibadah sosial insaniyah, oleh karenanya pengelolaan wakaf harus dapat dipertanggungjawabkan, yang antara lain adalah:

1. Tanggungjawab religius kepada Allah SWT atas segala prilaku, perbuatan 
dan tindakannya berdasarkan segala petunjuk perintahNya. Segala tindakan dantugasyangdilakukanolehparapihak sesuai dengan kewenangannya dalam pengelolaan harta wakaf, memiliki konsekwensiyangbersifattransendetal, yaitu harus dipertanggungjawakan dihadapan Allah SWT. Bagi Nazhir tanggungjawab pengelolaan ini adalah merupakan suatu beban amanah yang tidak ringan karena Nazhir tidak hanya sekedar melaksanakan apa yang menjadi niat Wakif, tetapi juga harus melaksanakan apa yang menjadi ketentuan Allah SWT yang secara verticaltentuharus dapat dipertanggung jawabkan kepadaNya. Sedangkan bagi Wakif sendiri mengharapkan adanya pemberian pahala yang secara terus menerus sepanjang masa atas amalan wakaf yang telah diberikan kepada masyarakat.

2. Tanggun jawab kelembagaan. Dalam pengelolaan harta benda wakaf disertai adanya tanggung jawab kepada pihak yang memberikan wewenang pengelolaan, yaitu tanggung jawab kepada lembaga yang lebih tinggi sesuaidengantingkatjenjang organisasi kenazhiran. Lembaga Nazhir ini yang merupakan sub organisasi pengelolaan dan pengembangan harta benda wakaf yang harus bertanggung jawab kepada lembaga yang ada diatasnya, yaitu bahwa sebagai Nazhir wajib melaporkan secara periodik semua yang menjadi tugas kewenangannya dan dari semua hasil pengelolaan yang telah diperolehnya kepada Badan Wakaf Indonesia(BWI).

3. Tanggungjawab hukum. Pengelolaan harta benda wakaf harus dapat dipertanggung jawakan secara hukum dalam arti bahwa pengelolaan tersebut dilakukan dengan tetap berdasarkan prosedur dan ketentuan hukum yang berlaku. Sebagai Nazhir atau sebagai orang yang diberikan wewenang dalam pengelolaan harta benda wakaf harus mampu mempertanggung jawabkan segala tindakannya, bahwa tindakan apa yang telah dilakukan dalam pengelolaan harta benda wakaf itu benar-benar sesuai dengan ketentuanketentuan yang berlaku. Jika kelak diketahui bahwa dalam melaksanakan amanah untuk mengelola harta benda wakaf tersebut diketahui ternyata melanggar aturan hukum yang berlaku maka Nazhir sebagai pemegang amanah pengelola harta benda wakaf yang bersangkutan harus siap diajukan kepengadilan.

4. Tanggungjawab sosial. Dalam pengelolaan harta benda wakaf itu bukan untuk kepentingan diri sendiri atau kelompok tertentu. Bahwa Nazhir sebagai pengelola harta benda wakaf harus ditujukan terhadap kepentingan masyarakat, dimana hasil pengelolaan harta benda wakaf adalah semata-mata hanya ditujukan untuk kepentingan peningkatan kesejahteraan masyarakat. Jadi sebagai Nazhir segala tindakannya harus dapat dipertanggungjawabkan kepada masyarakat, dan tidak 
melakukan tindakan yang tercela yang melanggar terhadap normanorma sosial yang berlaku dalam masyarakat.

5. Tanggungjawab moral. Pelaksanaan pengelolaan harta benda wakaf yang dilakukan semata-matahanya ditujukan untuk kepentingan kebaikan kehidupan masyarakat. Nazhir sebagai pengelola harus berpegangan kepada normanorma moral yang berlaku dalam masyarakat, maka segala prilakunya tidak boleh menyimpang dari normanorma moral. Secara moral setiap prilaku dapat dinilai baik buruknya oleh masyarakat pada setiap saat, maka kontrol masyarakat akan selalu menyertainya apakah tindakannya itu memang benar-benar bermoral atau tidak.

6. Tanggungjawab intelektual. Dalam pelaksanaan pengelolaan harta benda wakaf untuk dapat mencapai tujuan yang sepenuhnya sangat diperlukan adanya penguwasaan pengetahuan kemampuan dan ketrampilan yang memadai. Sebagai pengelola agar dapat mewujudkan tujuan yang diharapkan maka wajib memiliki bekal pengetahuan yang memadai, kemampuan dan ketrampilan professional yang memadai sesuai dengan bidang yang dikelolanya.

\section{c. Asas profesional.}

Dalam wakaf tugas pengelolaan merupakan bidang yang paling komplek, karena yang dapat menentukan suatu harta benda wakaf itu dapat bermanfaat dengan sebaik-baiknya atau tidak, pengelolaan itu dapat memenuhi keinginan sesuai harapan atau tidak adalah sangat bergantung pada pengelolaannya yang dalam hal ini dilakukan oleh Nazhir. Maka managemen pengelolaan wakaf itu harus dilakukan dengan secara baik dan benar agar dapat menghasilkan manfaat yang sebasar-besarnya untuk kepentingan masyarakat. Selama ini Nazhir melakukan tugas dan kewenangan untuk mengelola harta benda wakaf itu pada umumnya hanya berdasarkan kepercayaan semata, yang hanya dengan penguwasaan pengetahuan kemampuan ketrampilan seadanya saja dan hasilnya juga hanya bersifat sekedarnya. Sebagian besar Nazhir belum melakukan usaha pengelolaan harta benda wakaf itu benar-benar secara professional dan optimal, dengan hasil pengelolaan yang lebih besar dan manfaat yang lebih luas.

Agar pengelolaan harta benda wakaf itu dapat memberikan hasil yang lebih optimal maka sangat diperlukan adanya suatu management yang lebih professional. Maka bagi seorang Nazhir untuk dapat memenuhi harapan sesuai dengan fungsi dan tujuan wakaf dan agar dapat menghasilkan produktifitas ekonomi yang optimal dalam mengelola harta benda wakaf serta dapat membantu meningkatkan kesejahteraan masyarakat maka didalam management pengelolaan terhadap harta benda wakaf harus dipenuhi berbagai syarat sifat integritas pribadi, yang mutlak harus dimiliki bagi seorang Nazhir sebagai penunjang terhadap pelaksanaan tugas yang diembannya..

Adapun syarat-syarat sifat integritas pribadi yang harus dimiliki oleh seorang Nazhir adalah; 
1. Harus amanah (dapat dipercaya ).

Nazhir harus dapat dipercaya dalam melakukan tugas pengelolaan, bahwa pola management dipandang professional apabila seluruh system yang digunakan itu dapat dipercaya baik input maupun autputnya. Pengelolaan harta benda wakaf sangat bergantung kepada sumber daya yang ada pada Nazhir, maka Nazhir harus memiliki kemampuan yang memadai. Pengelolaan harta benda wakaf sangat bergantung pada Nazhir, dimana suatu pengelolaan harta banda wakaf itu dapat memberikan hasil dan manfaat yang optimal untuk kepentingan kesejahteraan masyarakat pada umumnya. Untuk dapat mengarah pada tujuan tersebut maka bagi seorang Nazhir harus memiliki kriteria sebagai berikut;

a. Standartpendidikanyang tinggi. Bahwa sebagai Nazhir tidak diragukan lagi terhadap penguwasaan pengetahuan yang memadai, memiliki wawasan yang luas, pemikiran yang tajam.

b. Memiliki kemampuan ketrampilan yang tinggi, sehingga diharapkan dapat menghasilkan produktivitas ekonomi yang tinggi dan kwalitas yang tinggi.

c. Memiliki kesadaran moral yang tinggi. Bahwa untuk pengelolaan yang sebaikbaiknya diperlukan adanya landasan kwalitas moral yang tinggi.

d. Pembagian kerja yang jelas. Bahwa didalam lembaga Nazhir didalamnya terdiri dari sekelompok orang, maka agar dapat bekerja secara serasi tidak terjadi tumpang tindih antara anggota Nazhir yang satu dengan yang lain maka harus ada sistem pembagian kerja yang jelas, tugas yang jelas.

e. Memiliki kesadaran hak dan kewajiban. Bahwa masing-masing Nazhir menyadari sepenuhnya apa yang menjadi haknya dan apa yang menjadi kewajibannya.

f. Memiliki rencana kerja yang jelas dan terarah, sehingga ada acuan yang nyata agar tidak terjadi kepincangan.

2. Shidiq (jujur).

Kejujuran adalah sifat mendasar pada kepribadian maupun pada program yang menjadi tanggungjawabnya sebagai seorang Nazhir. Sebagai seorang yang diberikan tugas, kewenangan dan tanggungjawab maka sifat pribadi yang jujur mutlak diperlukan.

3. Fathanah (cerdas/bijaksana).

Kecerdasan sangat diperlukan untuk menciptakan suatu program yang dapat diterimaolehmasyarakatdenganmemberikan harapan kehidupan yang lebih baik, lebih meningkat kepada masyarakat, dan mampu memenuhi keinginan masyarakat.

\section{Tabligh (terbuka).}

Kesediaan dalam memberikan informasi yang benar tentang pengelolaan dan pemanfaatan harta benda wakaf yang telah ataupun yang sedang berjalan kepada masyarakat.

7. Asas keadilan sosial.

Hasil pengelolaan tanah wakaf wajib diberikan kepada yang berhak untuk menerimanya berdasarkan keadilan sosial. Di dalam pandangan Islam ditegaskan bahwa harta itu adalah milik Allah SWT dan diberikan kepada orang-orang yang dikehendaki olehNya untuk dibelanjakan dijalan Allah SWT. Manusia diberikan hak 
oleh Allah SWT hanya untuk menguwasai saja, bukan sebagai pemiliknya. Harta dalam konsep Islam adalah harta Allah yang telah dikuasakan kepada manusia, artinya bahwa harta itu adalah milik Allah SWT sedangkan manusia itu terikat dalam membelanjakan hartanya dengan ketentuan-ketentuan yang disyari'atkan oleh Allah SWT. ${ }^{9}$ Manusia wajib memelihara harta yang dikuasai itu dngan penuh tanggung jawab baik didunai maupun di akhirat kelak. Manusia didunia sebagai hamba Tuhan Yang Maha Esa dan sebagai wakil Tuhan (Khalifatullah) dibumi yang menerima amanatNya untuk mengelola kekeyaan alam. ${ }^{10}$ Manusia didunia adalah sebagai Khalifah Allah SWT yang diberi wewenanguntukmengelolaseluruhkekayaan alam semesta itu untuk dipergunakan bagi kepentingan seluruh umat manusia.

Manusia menguwasai bumi, air dan kekayaan alam ini agar dikelola yang sebaikbaiknya untuk mewujudkan kesejahteraan bagi seluruh umat manusia. Manusia diberikan kewenangan untuk berusaha secara sungguh- sungguh dengan kemampuan sekuat tenaga untuk dapat memperoleh harta benda. Pemanfaatan harta benda yang dikuasainya agar dipergunakan untuk kepentingan dirinya, keluarganya dan untuk kepentingan masyarakat sekitarnya sesuai dengan tuntunan yang telah ditetapakan oleh syari'at Islam dan hukum positif yang berlaku.

Muhammad Mahmud Bably 1999, Al-Maal Fil Islam, terjemahan Abdul Fatah Idris, Kalam Mulia, Jakarta, hlm.35.

10 Kaelan dan Achmad Zubaidi, 2007, Pendidikan Kewarganegaraan, Paradikma, Yogyakarta, hlm.122.
Perwakafan mempunyai fungsi sosial dalam arti bahwa penggunaan hak milik oleh seseorang harus memberi manfaat secara langsung atau tidak langsung kepada masyarakat, jadi penggunaan harta oleh dirinya mempunyai dampak positif kepada masyarakat. Islam selalu menganjurkan agar selalu memelihara keseimbangan sebagai makhluk pribadi dan sebagai makhluk sosial. Hakekat sifat kodrat manusia secara filosofis adalah sebagai makhluk individu dan sebagai makhluk sosial, ${ }^{11}$ dalam kedudukan manusia sebagai makhluk sosial maka manusia tidak lepas keterikatannya dengan manusia yang lain atau dalam tata kehidupan masyarakat .

Keadilan sosial hendanya dilandasi dengan keimanan kepada Allah SWT. Dalam ajaran Islam melarang seseorang menimbun harta untuk kepentingan dirinya sendiri, sedangkan keadaan kondisi masyarakat disekitarnya hidup dalam keadaan kesusahan dan kemiskinan. Dalam kitab Suci Al Qur'an surat Adz-Dzariyat ayat 19 dinyatakan "dan didalam harta benda mereka ada hak bagi orang yang meminta (fakir miskin) dan bagi orang-orang yang terlantar atau orang yang tidak punya“. Islam selalu memberi petunjuk agar manusia selalu berada dalam kebersamaan dan bertolongmenolong dalam kebaikan, yang saling kasih mengasihi. Seseorang yang memiliki harta kekayaan yang berlebih hendaknya mendermakan sebagian hartanya secara iklas untuk kebajikan kaum fakir miskin sehingga terwujud kemakmuran secara adil dan merata. Islam juga melarang seseorang

11 Kaelan 2010, Pendikan Pancasila, Paradigma, Yogyakarta, hlm.96. 
yang memiliki harta kekayaan melakukan perbuatan dengan menghambur-hamburkan harta kekayaannya untuk hal-hal yang tidak bermanfaat.

Berdasarkan keyakinan bahwa apabila pengelolaan perwakafan dilaksanakan dengan baik maka akan dapat memberikan pengaruh dalam kehidupan sosial yang positif dan semakin meningkat dalam mencapai kesejahteraan masyarakat. Pelaksanaan ibadah perwakafan yang dikelola secara baik dapat membawa pengaruh besar dalam kehidupan kesejahteraan masyarakat, baik dalam bidang peribadatan, pendidikan, kesehatan dan kepentingan ekonomi masyarakat pada umumnya.

\section{Prinsip management pengelolaan harta tanah wakaf.}

Pengelolaan harta benda wakaf dalam rangka untuk mewujudkan suatu kesejahteraan umum maka Nazhir juga harus berpedoman kepada pinsip-prinsip pengelolaan harta tanah wakaf yang antara lain meliputi: 1. prinsip partisipasi, 2. prinsip penegakan hukum, 3. prinsip trasnparansi, 4. prinsip responsive, 5. prinsip orientasi kesepakatan, 6. prinsip keadilan, 7. prinsip efektifitas dan efisiensi, 8. prinsip akuntabilitas, 9. prinsip visi strategis. ${ }^{12}$

Pada prinsip partisipasi; meskipun Nazhir itu yang diberi kewenangan penuh untuk mengelola harta benda wakaf maka didalam pengambilan kebijakan-kebijakan yang mendasar sebaiknya dilibatkan partisipasi masyarakat, misalnya dalam

12 Trianto dan Titik Wulandari Tutik, 2007, Falsafah Negara dan Pendidikan Kewarganegaraan, Prestasi Pustaka Publisher, Jakarta, hlm.326. perencanaan penukaran atau penjualan terhadap harta tanah wakaf.

Prinsip penegakan hukum; penegakan hukum hakekatnya merupakan suatu usaha untuk mewujudkan ide-ide tentang keadilan, kepastian hukum dan kemanfaatan sosial menjadi kenyataan. ${ }^{13}$ Prinsip penegakan hukum merupakan landasan yang tidak dapat dikesampingkan dalam pengelolaan harta benda wakaf termasuk tanah wakaf. Didalam penegakan hukum yang pada hakekatnya mencakup juga tentang kewenangan untuk membuat aturan-aturan hukum guna mangatur kepentingan kehidupan masyarakat dan kewenangan untuk menegakan aturan yang berlaku.

Prinsip transparansi; dalam hal ini seorang Nazhir yang secara formal diberikan tugas dan kewenangan penuh untuk mengelola harta benda wakaf harus bersikaf transparan atau terbuka, sehingga Wakif maupun masyarakat dapat mengetahui secara jelas tentang segala usaha dan tindakan yang dilakukan oleh Nazhir dalam rangka pengelolaan harta benda wakaf.

Prinsip responsive; Nazhir dalam melakukan tugas dan kewenangan mengelola harta benda wakaf harus bersikaf responsif dalam arti Nazhir harus cepat tanggap terhadap peluang-peluang pengelolaan yang bersifat produktif, berbagai langkah-langkah yang perlu dilakukan, yang hasilnya guna membantu peningkatan kesejahteraan masyarakat.

Prinsip orientasi kesepakatan; dalam lembaga wakaf kedudukan Nazhir bukan

Riduan Syahrani, 1999, Rangkuman Intisari Ilmu Hukum, Citra Aditya Bakti, Bandung, hlm.192. 
sebagai pemilik harta benda wakaf, tetapi hanya diberi tugas dan kewenangan untuk mengelolanya, oleh karenanya dalam pengambilan keputusan harus didasarkan atas musyawarah untuk memperoleh kesepakatan dari berbagai pihak yang terkait dengan harta benda wakaf.

Prinsip keadilan; pemanfaatan terhadap hasil harta benda wakaf harus dilakukan secara adil, siapa yang berhak atas hasil pengelolaan dari harta benda wakaf itu. Pemanfaat terhadap harta benda wakaf sangat luas, antara lain untuk menunjang sarana peribadatan, pendidikan, kesehatan, membantu fakir miskin dan kepentingan umum yang lainnya, maka harus dilakukan secara proporsional yang berlandaskan kesetaraan keadilan.

Prinsip efektif dan efisien; Efektif dalam arti pengelolaan harta benda wakaf dapat dipergunakan untuk memenuhi kepentingan masyarakat yang seluasluasnya. dari berbagai kelompok dan lapisan sosial. Mampu memberikan kesejahteraan yang sebesar-besarnya dari berbagai kelompok dan lapisan sosial. Efisiensi dalam arti pemanfaatan hasil pengelolaan harta benda wakaf dilakukan dengan jalan yang sebaik mungkin jangan sampai terjadi suatu pemborosan.

Prinsip akuntabilitas; tugas dan kewenangan yang diberikan kepada Nazhir untuk mengelola harta benda wakaf harus dilakukan dengan penuh tanggungjawab dan dapat terkontrol, sehingga dapat menghindari kemungkinan adanya tindakan-tindakan penyimpangan.

Prinsip visi strategis; dalam pengelolaan harta benda wakaf yang cukup besar, khususnya tanah wakaf yang begitu luas maka Nazhir harus memiliki rencana kedepan yang lebih mantab dan jelas, sehingga harta benda wakaf yang dikelolanya itu dapat semakin berkembang.

\section{KESIMPULAN}

1. kegiatan pengelolaan pemanfatan harta tanah wakaf harus dilandsi oleh:
a. Asas manfaat
b. Asas tanggungjawab
c. Asas professional
d. Asas keadilan sosial.

2. Management pengelolaan pemanfaatan harta tanah wakaf harus berpedoman pada:
a. Prinsip partisipasi
b. Prinsip penegakan hukum
c. Prinsip transparansi
d. Prinsip responsive
e. Prinsif orientasi kesepakatan
f. Prinsip keadilan
g. Prinsip efektif dan efisien
h. Prinsif akuntabilitas
i. Prinsip visi strategis.

\section{DAFTAR PUSTAKA}

Ali Mohammad Daud, 1990, Asas-Asas Hukum Islam, CV Rajawali, Jakarta Anshori Abdul Ghofur, 2005, Hukum dan praktek perwahafan di Indonesia, Pilar Media, Yogyakarta.

Azhari Tahir, 1992, Wakaf dan sumberdaya ekonomi, Al Hikmah, Jakarta.

Bably Muhammad Mahmud, 1999, Al-Maal Fill Islam (terjemahan Abdul Fatah Idris), KalamMulia,Jakarta. 
Friedman Lawrence M, 1975, The Legal System, A social Science Perspektive, Rusell Sage Foundation, New York.

Kaelan dan Achmad Zubaidi, 2007, Pendidikan Kewarganegaraan, Paradigma, Yogyakarta.

Kaelan, 2010, Pendidikan Pancasila, Paradigma, Yogyakarta.

Praja S Juhaya \& Muklisin Muzarie, 2009, Pranata ekonomi Islam Wakaf, Pustaka Dinamika, Yogyakarta.

Trianto dan Titik Wulandari Tutik, 2007, Falsafah Negara dan Pendidikan Kewarganegraan, Prestasi Pustaka Publisher, Jakarta.

Soan Sholeh, 2004, Moral penegak hokum Indonesia dalam pandangan Islam, Agung Ilmu, Bandung.

Syahrani Riduan, 1999, Rangkuman Intisari Ilmu Hukum, Citra Aditya Bakti,Bandung

Manan Abdul, 2007, Hukum Wakaf Dalam Paradigma Baru di Indonesia, Varia Peradilan, Nomor 255, Edisi Februari 2007. 